\title{
Institutional Change and Coproduction of Public Services: The Effect of Charter Schools on Parental Involvement
}

\author{
Robert Bifulco \\ University of Connecticut \\ Helen F. Ladd \\ Duke University
}

\section{ABSTRACT}

\begin{abstract}
Recent discussions of school choice have revived arguments that the decentralization of governing institutions can enhance the quality of public services by increasing the participation of intended beneficiaries in the production of those services. We use data from the Schools and Staffing Survey to examine the extent to which the decentralization of authority to charter schools induces parents to become more involved in their children's schools. We find that parents are indeed more involved in charter schools than in observationally similar public schools, especially in urban elementary and middle schools. Although we find that this difference is partly attributable to measurable institutional and organizational factors, we also find that charter schools tend to be established in areas with above-average proportions of involved parents, and we find suggestive evidence that, within those areas, it is the more involved parents who tend to select into charter schools. Thus, while the institutional characteristics of charter schools do appear to induce parents to become more involved in their children's schools, such characteristics are only part of the explanation for the greater parental involvement in charter schools than in traditional public schools.
\end{abstract}

By participating in the production of public services, intended beneficiaries can often raise the quality of those services. For instance, residents can enhance the effectiveness of public police protection by organizing neighborhood watch groups and the effectiveness of fire protection by using fire-resistant building materials, by updating their wiring systems, or by taking precautions with stoves and fireplaces. Participation of the individuals served is perhaps most important for services such as education, counseling, and medical services that are intended to influence how people develop and function.

In the early 1980s experts on the structure of local governments argued that coproduction of public services can and should be encouraged through the use of institutional arrangements that provide opportunities and incentives for service agencies to cultivate

This research was supported by the Smith Richardson Foundation. The authors also wish to acknowledge the valuable research assistance provided by Shana Cook and helpful comments provided by Jane Hannaway and by anonymous reviewers. Address correspondence to Robert Bifulco at robert.bifulco@uconn.edu. 
client participation and for intended beneficiaries to make productive contributions (Ostrom and Ostrom 1977; Parks et al. 1981). The idea was that the efficiency of coproduction processes would be enhanced by institutional arrangements that decentralized authority to small groups and provided beneficiaries the opportunity to choose among multiple, autonomous service agencies (Kiser 1984; McGinnis 1999; Ostrom, Bish, and Ostrom 1988; Percy 1984).

More recently, versions of this argument have been revived in discussions of school choice. Hoxby (1999) provides evidence that in metropolitan areas with more school districts (and thus greater choice among schools) parents are more likely to immerse themselves in school decision making. Brandl (1998) argues that when parents are able to choose among small, autonomous schools, they are more likely to participate in school activities, and Hill, Pierce, and Guthrie (1997) argue that parents who have chosen their school are more committed to supporting its activities. Schneider et al. (1997) provide evidence that school choice stimulates parents to become more involved in a range of school-related activities, and Schneider, Teske, and Marschall (2000) suggest that increased participation in coproductive activity not only helps to improve service quality but can also develop a better-informed citizenry, foster trust among citizens, and enhance public confidence in government.

Charter school programs provide a good test case for the argument that institutional arrangements can enhance coproduction. First, given the recognized importance of student effort and parental involvement to the achievement of students, education is perhaps the prototypical case of a coproduced service. ${ }^{1}$ Second, charter school programs are specifically designed to provide a decentralized alternative to the centralized and bureaucratic delivery of education services and to provide parents the opportunity to choose their schools. For reasons discussed below, both decentralization and choice could well induce parents to become more involved in their children's schools. Thus, an examination of parental involvement in charter schools can provide insights into the role of institutional factors in promoting coproduction.

We use data from the Schools and Staffing Survey (SASS) to examine various explanations for differences in the extent of parental involvement in charter and traditional public schools. We find that charter schools do exhibit higher levels of parental involvement than observationally similar traditional public schools, and that part of this difference is attributable to the institutional and organizational characteristics of charter schools. We also find that charter schools tend to be established in areas with above-average proportions of involved parents, and we find suggestive evidence that, within those areas, more involved parents tend to select into charter schools. Thus, while the institutional characteristics of charter schools appear to induce parents to become more involved in their children's schools, such characteristics are only part of the explanation for the higher levels of participation in those schools.

1 The effective schools literature has long emphasized the importance of parental involvement in improving school quality and student achievement (see Purkey and Smith 1983), and parental involvement is an important element of several comprehensive school reform models such as Accelerated Schools and the School Development Project. Case studies by Murnane and Levy (1998) suggest that the activities of parent-teacher associations have substantial effects on student performance. Statistical analyses of the impact of parental involvement have had mixed results, but in general they have found a positive relationship between parental involvement and student attainment and achievement (Antone and McLanahan 1991; McMillan 1999; Muller 1993; Sui-Chu and Willms 1996; Witte and Walsh 1990). 


\section{WHY MIGHT PARENTS BE MORE INVOLVED IN CHARTER SCHOOLS?}

Charter schools are publicly funded schools that operate largely independently of the districts and boards that govern most public schools, often under the auspices of a nonprofit organization. They are established through a contract or charter granted by an authorized public agency, and their public funding is tied to the number of students they enroll. They are typically open to all students, and when capacity is reached, they are required to select students randomly. The first law providing for the establishment of charter schools was passed in Minnesota in 1991. Since then, forty states and the District of Columbia have adopted charter school programs.

Parental involvement can be distinguished based on whether it takes place in the home or at school and whether it involves individual or collective actions (McMillan 1999). Parental involvement at home includes helping a student with homework or monitoring student progress. Involvement at school includes attending parent-teacher conferences, attending school events, volunteering services of various sorts, or participating in school management teams. Some forms of parental involvement primarily benefit the individual child; others provide collective benefits to a wider group of students in the school. In this study we focus on forms of parental involvement that take place in school, including both individual and collective actions. ${ }^{2}$

The main hypothesis is that parents tend to become more involved in charter schools than in traditional public schools because of certain organizational characteristics of charter schools, such as their small size, and specific aspects of their institutional environments. In terms of institutional context, charter schools differ from most public schools in that they tend to have more autonomy and are schools of choice, which means parents choose to enroll their children, and the funding for each charter school depends on its ability to attract and retain students. In this section we consider ways in which these organizational and institutional features might provide charter school parents opportunities and incentives to participate in school activities and charter school officials the opportunity and incentive to promote parental involvement.

\section{Small Size}

As we document below, charter schools are considerably smaller than traditional public schools. A large literature on student involvement tracing back to the work of Barker (1964) argues that students are more involved in extracurricular activities at small schools than at large schools. Because small schools often offer the same activities as large schools, a higher proportion of students have the opportunity to participate. In addition, greater face-to-face familiarity in small schools breaks down social and psychological barriers to participation. Although these arguments typically apply to the involvement of students, similar arguments might be made about the involvement of parents in collective activities such as parent-teacher associations or school management team meetings. In addition, small schools may induce greater parental involvement because individual parents may

2 The distinction between parental involvement at home and in school corresponds to a more general distinction between "independent" coproduction, where citizens effectively produce their own outcomes above and beyond the contributions of government, and "participatory" coproduction, where citizens work with government to improve what government does for them. The latter is more plausibly linked to citizenry trust and confidence in government. The authors thank Amy Donahue for pointing out this more general distinction. 
believe their actions will have more of an impact on the school than would be the case in larger schools.

\section{Autonomy}

A primary purpose of most charter school legislation is to establish a new type of school in which school personnel have significant autonomy over matters of curriculum, instruction, personnel, budget, and student discipline. When greater discretion is allowed at the school level, parents might feel they can exert greater influence over the programs and policies that matter to them. Thus, parents might perceive greater returns to their involvement, which could induce more parents to devote the time and effort that such involvement requires. Such considerations most directly influence the decision to participate in collective efforts to influence school policy through the parent-teacher association and school management teams. In addition, when a school has more discretion over how to handle individual student issues, parents might feel they have more to gain from participating in individual parent-teacher conferences.

\section{Parent-School Match}

The fact that charter schools are schools of choice distinguishes them from many public schools. To be sure, affluent parents are often able to choose the public school their child attends through their choice of residential location, and many school districts now offer magnet schools and other schools of choice within the traditional public school sector. Nonetheless, in many areas, parents may well face the option of sending their child to the assigned neighborhood school or to a charter school. The fact that parents can choose to enroll their child in a charter school could well influence the benefits and costs of becoming involved.

Parents who have specifically chosen a school are more likely, on average, to be comfortable interacting with school personnel and to have policy and program preferences that match those of the school staff than is the case for parents whose children are simply assigned to a particular school. ${ }^{3}$ On the one hand, a closer match in preferences might reduce a parent's perceptions of the need for, and thus the potential returns to, involvement (Hirschman 1970; McMillan 1999). On the other hand, when staff and parents share programmatic preferences, parental participation in school decisions is likely to cause less conflict and to be less frustrating for both parents and staff, thereby reducing the psychological costs to the parents of becoming involved. Thus, under certain circumstances, the fact that parents choose charter schools could well increase the likelihood of parents becoming involved.

\section{Competition}

Citing bargaining theory, which suggests that negotiations result in agreements closer to a party's preferences when that party has outside options, Hoxby (1999) argues that the threat of exit can increase parental influence over school policy. Thus, parents might get

3 Schneider et al. (1997) find that parents who have actively chosen their child's school are more likely to trust their child's teacher most or all of the time than are parents whose children attend the school assigned to them. 
a greater return from their involvement when they have choices to enroll their children elsewhere. Of course, parents also have less incentive to try to influence school policy when they can simply choose another school more to their liking. Thus, the predicted effect of providing parents an exit option on parental involvement is ambiguous. ${ }^{4}$

Closely related is the notion that schools that have to compete for students have incentives to promote parental involvement. Although parental involvement is typically considered an input into the education production process that is costly for parents (McMillan 1999; Ostrom and Ostrom 1977), some forms of involvement might provide direct consumption benefits for parents. Parent education workshops and courses are obvious examples. Some parents may also enjoy volunteering in the school or participating on school management teams. To the extent that parental involvement provides direct consumption benefits, charter schools have incentives to provide more opportunities for parents to get involved as a way to attract students.

Even if parents do not view their involvement in schools as a consumption good, schools forced to compete for students might face other incentives to encourage parent involvement. Activities in which parents participate provide a mechanism for school officials to collect information about parental needs and preferences, which helps them to ensure that their product is attractive to their target market (Chubb and Moe 1990). Also, school officials may use such activities to enlist parents to assist in efforts to market the school and recruit additional students.

\section{Charter School Location, Self-Selection, and the Effects of Sorting}

Each of the preceding considerations implies that the introduction of charter schools might stimulate additional parental involvement. Alternatively, if it is the more active parents who tend to select into charter schools, a higher level of parental involvement in charter schools relative to traditional public schools need not imply that charter schools increase the aggregate involvement of parents.

We can imagine two processes by which parents with a greater proclivity toward getting involved might end up selecting charter schools. First, charter schools might be established in areas where parents are more involved. In this case, if charter schools attracted children whose parents were typical for the local area, parents in charter schools would be more active than parents from a random sample of traditional public schools covering a broader area. Second, within any local area, charter schools might attract parents from surrounding schools who tend to be more active than the typical parent in those schools. Under either scenario, a high level of parental involvement at charter schools need not imply that charter schools have induced parents to become more involved than they would have been in the absence of charter schools.

If charter schools attract some of the more involved parents away from traditional public schools and the benefits of parental involvement are to some extent collective, the achievement of students in the traditional public schools might suffer, even though individual parents are no more or less involved in schools than they otherwise would have been. Similarly, if highly involved parents congregate in charter schools, their children

4 In the terms developed in Hirschman's (1970) classic treatment, the question is whether "exit" and "voice" are complements or substitutes. If exit options do in fact increase parental influence, and thus parental involvement, traditional public schools subject to charter school competition, as well as charter schools, can expect to benefit. 
might benefit even if individual parents do not change their behavior at all. The net effect on student achievement is uncertain.

As well as affecting the distribution of parents with different proclivities for involvement, parental sorting can influence the decisions that individual parents make about how much to participate. Schneider, Teske, and Marschall (2000) hypothesize that some of the collective benefits of parental involvement require a critical mass of parents willing to participate. If a parent is unable to find enough other willing parents, he or she may choose not to participate. This same parent, however, might participate in another school where there are more willing parents. If the sorting generated by charter schools reduces the number of willing parents in a particular school below the critical mass, then some parents in that school will participate less than they would have in the absence of charter schools. ${ }^{5}$ At the same time, parents who move from public schools with less than the critical mass to charter schools with a critical mass of engaged parents may increase their level of involvement. Thus, the behavioral effects of sorting can magnify differences between charter schools and traditional public schools.

\section{DATA}

The analyses presented here use data from the school and principal components of the restricted-use Schools and Staffing Survey (SASS). Conducted by the National Center for Education Statistics (NCES), the SASS is the largest, most extensive survey of schools in the United States today. The SASS asks similar questions of respondents in both traditional public and charter schools. The consistent set of questions and large sample sizes allow reliable national comparisons of charter and traditional public schools in aggregate. The large samples also allow extensive disaggregation of comparisons by school characteristics, such as primary versus secondary schools, and urban versus nonurban areas.

The SASS uses a stratified probability sampling procedure to select a set of traditional public schools that is representative at the national and state levels. In addition, the 19992000 target sample for the SASS includes the universe of charter schools in the country that were open during the 1998-1999 school year and that remained open during the 19992000 school year. The 1999-2000 SASS targeted 9,527 traditional public schools, 9,404 of which had an eligible principal, and 1,010 charter schools with 988 eligible principals. After insufficiently complete interviews were discarded, the response rates for public schools, public school principals, charter schools, and charter school principals were 88.5, 90.6, 86.1, and 90.2 percent, respectively. The SASS data files provide sampling weights, which are used in the analyses below, that account for each school's probability of being selected and unit nonresponse. Particular items from each survey had lower response rates, and missing values were imputed by NCES. However, none of the items used in the analyses below had item response rates lower than 90 percent. $^{6}$

The comparisons between charter schools and traditional public schools presented below are based on the 1999-2000 SASS and are limited to states that had charter school programs as of 1998. A limitation of this study is that the SASS is not designed as a panel,

\footnotetext{
5 Some parents might respond by substituting noncollective or individual forms of parental involvement for collective forms of involvement. In this case, effects on student achievement will depend on the marginal benefits of each type of involvement.

6 For more information on the SASS sampling design, response rates, imputation procedures, and sampling weights, see Tourkin et al. (2004).
} 
Table 1

Respondents to the Schools and Staffing Survey, by Component, in States with Charter Schools

\begin{tabular}{|c|c|c|c|c|}
\hline \multirow[b]{2}{*}{ Questionnaire } & \multicolumn{3}{|c|}{ Traditional Public Schools } & \multirow{2}{*}{$\frac{\text { Charter Schools }}{1999-2000}$} \\
\hline & 1993-1994 & 1999-2000 & Both Years & \\
\hline School & 4,420 & 4,659 & 711 & 870 \\
\hline Principal & 4,295 & 4,726 & 734 & 891 \\
\hline School and Principal & 4,019 & 4,332 & 687 & 800 \\
\hline
\end{tabular}

so the sample of schools surveyed changes with each administration. Because each wave of the SASS includes approximately 10 percent of U.S. schools, however, many schools are included in both the 1993-1994 and 1999-2000 surveys. Given that 1993-1994 predates the establishment of the vast majority of charter schools, linking data from the 1993-1994 and 1999-2000 surveys for the subset of schools included in both samples allows us to analyze changes in parental involvement at traditional public schools before and after the introduction of charter schools. Table 1 provides information on the total number of respondents for the various samples and survey components used in this study. Exact sample counts used in the analyses below vary and are detailed in the notes to each table.

The primary measures of parental involvement examined in this study are based on items from the school questionnaire, which ask about the proportions of parents who participate in various school activities. An additional measure comes from the survey of principals and concerns the extent to which the principal perceives lack of parental involvement to be a problem. Thus, all our measures of parental involvement are based on perceptions, rather than actual activity counts, and might be influenced by the incomplete knowledge of respondents, their subjective expectations, and their desires to make their school look good. Assuming this type of measurement error is randomly distributed across schools, the primary effect is to reduce the proportion of the variation in parental involvement that can be explained. Measurement error in the dependent variable would bias the analysis only if it were systematically related to the explanatory variables of interest.

The explanatory variables in our various models are drawn from the principal and the school components of the SASS and the NCES's Common Core of Data (CCD). By linking the SASS and the CCD, we were able to obtain more complete measures of student body characteristics and also public school addresses, which, together with an additional restricted-use file of charter school addresses, allowed us to compute measures of the distances from each traditional public school to the nearest charter school.

These data allow informative national comparisons of charter schools and traditional public schools. Given the cross-sectional nature of the SASS and the limitations of its measures of parental involvement, however, this study is best viewed as an exploratory analysis. More rigorous tests of the hypotheses about parental involvement will require more in-depth, localized comparisons based on data directly from parents.

\section{ARE LEVELS OF PARENTAL INVOLVEMENT HIGHER IN CHARTER SCHOOLS?}

Our basic measures of parental involvement are based on SASS questions that solicit information about the proportions of parents who participate in various activities, ranging from open houses to budget decisions, offered by the schools. Although not all schools offered every activity, preliminary analyses indicated that, controlling for certain basic 
characteristics of schools, such as their location and the demographic characteristics of their students, charter schools were more likely than traditional public schools to offer each activity. ${ }^{7}$ Schools that reported providing the activity were asked to indicate the proportion of parents who participated and were given the options "Few," "Less than half," "About half," "More than half," and "Most." Table 2 compares the average ratings of parental participation based on a one to five scale (with one indicating "Few" and five indicating "Most") separately for primary (which includes both elementary and middle schools) and high schools, by charter school status.

The figures show that parental participation is consistently higher in charter schools than in traditional public schools for most of the activities listed. The only exceptions at the primary level are open houses and schoolwide parent-teacher conferences for which the differences are too small to be statistically significant. At the high school level, which exhibits lower levels of parental participation across the board, the differences between charter and traditional public schools follow a similar pattern.

The final two rows of table 2 report two summary indices, one for parental participation in school events, which is based on the first three items in the table, and the other for participation in school operations, which is based on the final four items. These groupings emerged from an exploratory factor analysis of all nine items. For each index we averaged the relevant items in table 2 and converted the average into a standard score with a mean of zero and a standard deviation of one, using the means and standard deviations for all traditional public schools. ${ }^{8}$ The indices reveal that at the primary level charter school parents are more involved than other parents in both school events and school operations. At the secondary level charter school parents are more involved than other parents in school operations but not in school events. The negative index values for three of the four indices at the secondary level highlight the below-average participation of the parents of older students.

We supplement these two indices of parental involvement with a third measure from the principal survey. Principals were asked, "To what extent is lack of parental involvement a problem in this school," with the options of responding, "a serious problem," "a moderate problem," "a minor problem," or "not a problem." In the heading of table 3, and throughout this article, we refer to this measure as the principal's rating of parental involvement, although it is important to keep in mind that it is the principal's rating of the extent to which lack of parental involvement is a problem. A shortcoming of this measure is that it reflects not only the principal's perceptions of how much parents are involved in the school but also his or her expectations about what is desirable. Its advantage is that it is also available in the 1993-1994 SASS, a fact that is important for some of our analysis.

The top panel of table 3 indicates that, at the primary level, principals of charter schools were far less concerned about insufficient parental involvement than were their traditional public school counterparts. In particular, the charter school principals were less likely to report that lack of parental involvement is a serious or moderate problem and far

7 The controls used were urbanicity, grade level, percentage minority, percentage eligible for free lunch, percentage limited English proficient, and enrollment. In most cases, the adjusted differences between charter schools and traditional public schools in the likelihood of offering a particularly activity were small (less than 7 percent) but statistically significant. The adjusted differences between traditional public schools and charter schools in percentage offering participation in school events were particularly small, ranging from 1 to 4 percent.

8 The operations involved in constructing these indices assume it is appropriate to treat the component items as interval scales. The Cronbach's alpha for the index of participation in school events is 0.772 and for the index of participation in school operations is 0.773 . 
Table 2

Parental Participation: Comparisons between Charter Schools (Charter) and Traditional Public Schools (TPS)

\begin{tabular}{|c|c|c|c|c|}
\hline & \multicolumn{4}{|c|}{ Average Estimate of Parent Participation ${ }^{\mathrm{a}}$} \\
\hline & \multicolumn{2}{|c|}{ Primary Schools ${ }^{\mathrm{b}}$} & \multicolumn{2}{|c|}{ Secondary Schools ${ }^{\mathrm{c}}$} \\
\hline & Charter & TPS & Charter & TPS \\
\hline Open House or Back-to-School Night & 3.95 & 3.95 & 2.84 & 2.89 \\
\hline Schoolwide Parent-Teacher Conferences & 4.25 & 4.14 & 3.05 & 2.99 \\
\hline Subject Area Events & $3.68 * *$ & 3.39 & $2.44 * *$ & 2.72 \\
\hline Parent Education Workshops & $2.34 * *$ & 1.70 & $1.99 * *$ & 1.58 \\
\hline Written School-Parent Contract & $4.34 * *$ & 3.52 & $3.79 * *$ & 2.67 \\
\hline Parents as Volunteers in School & $2.58 * *$ & 1.85 & $1.81 * *$ & 1.33 \\
\hline Parents Involved in Instructional Issues & $2.00 * *$ & 1.52 & $1.56^{* *}$ & 1.27 \\
\hline Parents Involved in Governance & $1.69 * *$ & 1.26 & $1.40 * *$ & 1.19 \\
\hline Parents Involved in Budget Decisions & $1.47 * *$ & 1.24 & $1.39 * *$ & 1.14 \\
\hline Index 1 (School Events $)^{\mathrm{d}}$ & $0.315 * *$ & 0.203 & -0.684 & -0.669 \\
\hline Index 2 (School Operations) $^{\mathrm{e}}$ & $0.797 * *$ & 0.101 & $0.082 * *$ & -0.368 \\
\hline \multicolumn{5}{|c|}{ 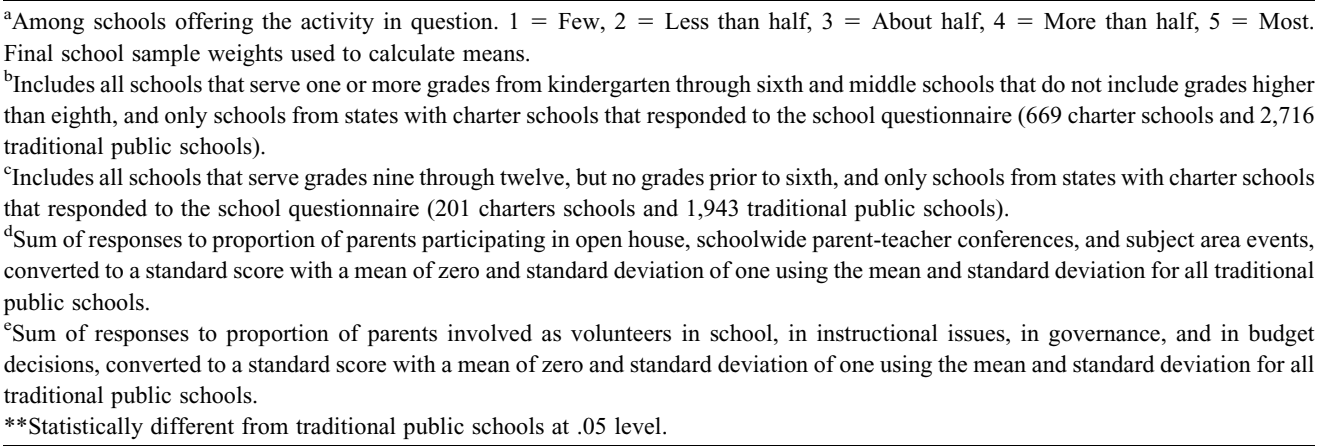 } \\
\hline
\end{tabular}

more likely to say that is it is not a problem. At the secondary level the same patterns between sectors emerge, but the differences are less marked. Thus, all three measures of parental involvement indicate that parents of charter school students at the primary level are more involved than their counterparts in traditional public schools. At the secondary level the differences between sectors are smaller and somewhat less consistent.

Our main empirical task is to determine why parental involvement is so high in charter schools. If aspects of charter schools serve to elicit additional involvement from individual parents without reducing parental involvement in traditional public schools, we can conclude that the net impact of the charter school option on aggregate parental involvement is positive, and presumably beneficial. If, however, high levels of parental involvement in charter schools merely reflect the location of charter schools in areas with above-average levels of parental involvement, or are achieved by attracting the most involved parents away from nearby schools, then the policy implications are more ambiguous.

\section{DO INSTITUTIONAL FACTORS EXPLAIN HIGHER LEVELS OF INVOLVEMENT IN CHARTER SCHOOLS?}

Table 4 compares charter schools to traditional public schools on several measures that are potentially related to parental involvement. In the analysis below, we treat the first set of variables - those related to the location and the demographic characteristics of the 
Table 3

Principal Ratings of Parental Involvement: Charter Schools and Traditional Public Schools (TPS)

\begin{tabular}{|c|c|c|c|}
\hline & \multirow[b]{2}{*}{ Lack of Parental Involvement Is: } & \multicolumn{2}{|c|}{ Percentage of Principals Responding } \\
\hline & & Charter & TPS \\
\hline $\begin{array}{l}\text { Primary Schools }{ }^{\mathrm{a}} \\
\chi^{2}=22.58 ; p=.0000\end{array}$ & $\begin{array}{l}\text { A serious problem } \\
\text { A moderate problem } \\
\text { A minor problem } \\
\text { Not a problem }\end{array}$ & $\begin{array}{r}9.0 \% \\
19.7 \% \\
34.8 \% \\
36.5 \%\end{array}$ & $\begin{array}{l}11.6 \% \\
30.2 \% \\
36.3 \% \\
21.9 \%\end{array}$ \\
\hline $\begin{array}{l}\text { Secondary Schools }{ }^{\mathrm{b}} \\
\chi^{2}=7.46 ; p=.0494\end{array}$ & $\begin{array}{l}\text { A serious problem } \\
\text { A moderate problem } \\
\text { A minor problem } \\
\text { Not a problem }\end{array}$ & $\begin{array}{l}23.3 \% \\
26.2 \% \\
33.7 \% \\
16.9 \% \\
\end{array}$ & $\begin{array}{l}20.4 \% \\
36.6 \% \\
30.9 \% \\
12.1 \% \\
\end{array}$ \\
\hline
\end{tabular}

Note: Proportions calculated using responding principals from schools in states with charter schools as of 1998 and sample weights for principal survey. $\chi^{2}$ and corresponding $p$-values are for tests of independence of the principal's rating and the charter school indicator. ${ }^{a}$ Defined as in table 2 and includes 693 charter school principals and 2,763 traditional public schools principals.

${ }^{\mathrm{b}}$ Defined as in table 2 and includes 198 charter school principals and 1,963 traditional public schools principals.

school - as control variables. We hypothesize that these variables would be related to the level of parental involvement in a school regardless of the institutional arrangements under which the school operates. The remaining measures represent the organizational and institutional characteristics of charter schools (small size, autonomy, parent-school matches, and competition for students) that provide the mechanisms through which charter schools might elicit higher levels of parental involvement.

\section{School Location and Student Demographics}

Table 4 shows that, among primary schools, charter schools are almost twice as likely and, among secondary schools, are more than three times as likely as traditional public schools to be located in urban areas. Charter schools are also significantly less likely to be located in rural areas. Compared with traditional public schools, charter schools serve higher percentages of minority and low-income (as measured by free-lunch eligibility) students, although differences in the percentage of low-income students is significant only for secondary schools. ${ }^{9}$ Among primary schools, charter schools have slightly lower percentages of limited English proficient (LEP) students than traditional public schools. There is no significant difference between sectors at the secondary level.

\section{Organizational and Institutional Factors}

Turning to the organizational and institutional factors, we see that, on average, charter schools are about half the size of traditional public schools at the primary level, and they are less than a third of the size at the secondary level. We hypothesize that the smaller schools elicit involvement that would not have emerged in larger schools and, hence, that these size differences could account for part of the observed difference in parental involvement between the two sectors.

9 In general, eligibility for free and reduced-price lunch is viewed as a more accurate proxy for family poverty in the case of primary than of secondary school students, given that older students are often reluctant to identify themselves as coming from low-income families. Whether students attending charter high schools would be more or less likely than those in traditional high schools to identify themselves as poor is hard to predict. 
Table 4

Potential Determinants of Parental Involvement: Mean Differences between Charter Schools and Traditional Public Schools (TPS)

\begin{tabular}{|c|c|c|c|c|}
\hline & \multicolumn{2}{|c|}{ Primary Schools ${ }^{\mathrm{a}}$} & \multicolumn{2}{|c|}{ Secondary Schools ${ }^{\mathrm{b}}$} \\
\hline & Charter & TPS & Charter & TPS \\
\hline \multicolumn{5}{|l|}{ School Location and Demographics } \\
\hline Located in urban area ${ }^{c}$ & $0.505^{* *}$ & 0.261 & $0.594 * *$ & 0.192 \\
\hline Located in rural $\operatorname{area}^{\mathrm{c}}$ & $0.152^{* *}$ & 0.228 & $0.138^{* *}$ & 0.323 \\
\hline$\%$ Minority & $0.494 * *$ & 0.388 & $0.515^{* *}$ & 0.310 \\
\hline$\%$ Eligible for free lunch & 0.460 & 0.438 & $0.467 * *$ & 0.333 \\
\hline \% Limited English proficient & $0.054 * *$ & 0.078 & 0.042 & 0.033 \\
\hline \multicolumn{5}{|l|}{ School Size } \\
\hline Enrollment & $272 * *$ & 504 & $237 * *$ & 819 \\
\hline \multicolumn{5}{|l|}{ School Level Autonomy } \\
\hline External control $^{\mathrm{d}}$ & $-1.042 * *$ & 0.000 & $-0.870^{* *}$ & -0.001 \\
\hline School control ${ }^{\mathrm{e}}$ & $0.393 * *$ & -0.005 & $0.340 * *$ & 0.015 \\
\hline \multicolumn{5}{|l|}{ Parent-School Match } \\
\hline Ethnic homogeneity & $0.775^{* *}$ & 0.755 & 0.758 & 0.763 \\
\hline Poverty homogeneity & $0.719^{* *}$ & 0.688 & 0.704 & 0.716 \\
\hline Ratio of minority teachers to minority students & 0.045 & 0.039 & 0.035 & 0.043 \\
\hline \multicolumn{5}{|l|}{ Efforts to Promote Parental Involvement } \\
\hline Staff member assigned to work on parental involvement ${ }^{\mathrm{c}}$ & 0.580 & 0.588 & $0.576^{* *}$ & 0.439 \\
\hline A log of parent participation maintained ${ }^{\mathrm{c}}$ & 0.749 & 0.754 & 0.552 & 0.497 \\
\hline Reliable system of communication ${ }^{c}$ & $0.955^{* *}$ & 0.973 & 0.879 & 0.924 \\
\hline Services to support parent participation ${ }^{\mathrm{c}}$ & $0.494 * *$ & 0.441 & 0.200 & 0.204 \\
\hline A parent drop-in center ${ }^{\mathrm{c}}$ & 0.296 & 0.259 & $0.203^{* *}$ & 0.120 \\
\hline $\begin{array}{l}\text { Teachers required to send information to } \\
\text { parents explaining school lessons }{ }^{\mathrm{c}}\end{array}$ & $0.646^{* *}$ & 0.584 & $0.399 * *$ & 0.488 \\
\hline $\begin{array}{l}\text { Teachers required to provide activities that } \\
\text { parents can do at home with children }\end{array}$ & $0.556^{* *}$ & 0.506 & 0.221 & 0.239 \\
\hline $\begin{array}{l}\text { Teachers required to create homework } \\
\text { assignments that involve parents }\end{array}$ & $0.414 * *$ & 0.342 & 0.122 & 0.100 \\
\hline
\end{tabular}

${ }^{a}$ Defined as in table 2. Means calculated using schools from charter school states that responded to both the school and principal surveys (2,520 traditional public schools and 618 charter schools) and principal sample weights.

${ }^{\mathrm{b}}$ Defined as in table 2. Means calculated using schools from charter school states that responded to both the school and principal surveys (1,812 traditional public schools and 182 charter schools) and principal sample weights.

${ }^{\mathrm{c}} 1=$ Yes, $0=$ No.

${ }^{\mathrm{d}}$ Average rating (converted to standard score with mean zero and standard deviation one, using mean and standard deviation of all traditional public schools in charter school states) of state, school board, and district officials control over performance standards, curriculum, professional development, teacher evaluation, teacher hiring, discipline policy, and budget decisions on a $1-5$ scale, where $1=$ No influence and $5=$ A great deal of influence.

${ }^{\mathrm{e}}$ Average rating (converted to standard score with mean zero and standard deviation one, using mean and standard deviation of traditional public schools in charter school states) of principal and teacher control over performance standards, curriculum, professional development, teacher evaluation, teacher hiring, discipline policy, and budget decisions on a $1-5$ scale, where $1=$ No influence and $5=$ A great deal of influence.

**Significantly different than traditional public schools at .05 level.

The next two variables indicate the extent of school-level autonomy over school policy and operations. These variables are constructed from principals' responses to the following question: "Using the scale 1-5, where 1 is 'No influence' and 5 is 'A great deal of influence,' how much ACTUAL influence do you think each group or person has on 
decisions concerning the following activities?" The activities include setting performance standards, establishing curriculum, determining the content of professional development, evaluating teachers, hiring new teachers, setting discipline policy, and deciding how the budget will be spent. For each of these seven activities, respondents are asked about the following five groups: the state department of education or other state-level body, the local school board, school district staff, the principal, and teachers. ${ }^{10}$ Exploratory factor analysis using these thirty-five items revealed two underlying constructs, one measure of external control that reflects the influence of those groups outside and hierarchically above the school (that is, the state, school board, and district officials) and the other of internal control that reflects the influence of the principal and teachers. We averaged the relevant responses for each measure and used the means and standard deviations for all traditional public schools to construct standard scores of external and internal control. Lower levels of external control and higher levels of internal control indicate more autonomy.

As indicated in table 4, charter schools are substantially less subject to external control. Among primary schools, external groups exercise more than one standard deviation less influence in charter schools than in traditional public schools, with large differences emerging for secondary schools as well. With respect to internal control, the differences between charter schools and traditional public schools are somewhat smaller, but charter schools still exhibit substantially higher ratings of autonomy by this measure.

A third potential difference between charter schools and traditional public schools is the match between parents and schools. Unfortunately, the SASS provides little indication of parents' comfort level with the school or of the match between the preferences of parents and those of the school staff because it does not include a survey of parents. At best, we can devise rough proxies of preference match and social comfort. Kerbow and Bernhardt (1993) provide evidence that schools with high concentrations of minority students show relatively high levels of parental involvement and that minority parents increase their involvement in the school as the proportion of minority teachers increases. These findings are consistent with the assumption that parents tend to be more comfortable with, or are more likely to have preferences similar to, other parents and teachers when those other parents and teachers are similar to them ethnically or in other ways.

Thus, we create three variables to serve as proxies for the parent-school match. The first is a measure of ethnic homogeneity used by Moody (2001) in a study of racial relations in schools. If we divide a school into minorities $(k=1)$ and nonminorities $(k=2)$, the measure of ethnic homogeneity is defined as $\Sigma p_{k}^{2}$, where $p_{k}$ is the proportion of group $k$ in the school. This measure takes on higher values for schools that are either predominantly minority or predominantly nonminority. We create a similar measure of poverty homogeneity, where the groups are students who are eligible for free lunch and those who are not. Finally, the ratio of minority teachers to minority students captures the ethnic match between teachers and students, where a higher ratio indicates a closer match. Among primary schools, charter schools are more ethnically and socioeconomically homogeneous than are traditional public schools. Charter schools also exhibit a slightly closer, but not statistically significant, parent-teacher match. Among secondary schools, no significant differences in parent-school match emerge between the two sectors.

10 For some activities, principals were asked to rate the influence of other groups in addition to these five. These five, however, are the only groups that were asked about for all seven activities and for which there were meaningful ratings for more than 90 percent of the schools. 
The final eight measures in table 4 indicate the probabilities that schools have implemented various programs and services intended to increase parental involvement. These are the types of efforts we would expect to observe in schools that face competition for students, provided that schools view parental involvement as a way to attract students. Thus, these measures reflect one of the mechanisms through which competition might influence parental involvement. As discussed earlier, competition could also induce parents to increase involvement independent of any actions taken by the school. ${ }^{11}$

Among primary schools, charter schools are significantly more likely to provide services to support parental participation, such as transportation or child care, and are also significantly more likely to require teachers to make efforts to involve parents in student learning at home. Although charter schools are somewhat less likely to have a reliable system of communicating with parents, nonetheless over 95 percent of charter schools report having such a system. Among secondary schools, charters are more likely to assign a staff member to work on parental involvement and to provide a parent drop-in center but are less likely to require teachers to send information to parents explaining school lessons.

\section{Isolating the Influence of Organizational and Institutional Factors}

The question now is the extent to which the organizational and institutional measures listed in table 4 account for the differences in parental involvement between observationally similar charter and traditional public schools. Our strategy is first to estimate charter school effects, allowing the effects to differ for schools in nonurban and urban areas, controlling only for school location and demographic variables. The charter school coefficients from this first model represent the average difference in parental involvement between charter schools and observationally similar schools. Next, we add to the regression models measures of school size, school autonomy, parent-school match, and efforts to promote parental involvement. The more that the inclusion of these variables reduces the magnitude of the estimated charter school effects, the greater is the proportion of those effects that can be attributed to the institutional and organizational features of charter schools. Any remaining charter school effect reflects either the influence of unmeasured institutional factors or of determinants of parental sorting not captured by other variables in the model.

The dependent variables in the three parts of table 5 are, respectively, the index of parent participation in school events, the index of parent participation in school operations, and the principal's rating of parental involvement. ${ }^{12}$ Although we have estimated each model separately for primary (which includes both elementary and middle schools) and secondary schools, we present here only the results for primary schools because of the

11 Hoxby (1999) uses concentration of school districts in an area as measured by the Herfindahl index to provide a measure of competition faced by public schools. Other charter school studies have used measures of distance from charter schools (Bifulco and Ladd forthcoming; Holmes, DeSimone, and Rupp 2003) or the percentage of students in a district who attend charter schools (Hoxby 2003) as measures of the amount of competition from charter schools faced by traditional public schools. None of these more direct measures of competition provide accurate indices of the amount of competition faced by charter schools and provide little information about the differences in the amount of competition between charter schools and traditional public schools. In the absence of competition measures suitable for our purposes, we have chosen to focus on indicators of at least one of the mechanisms through which competition might affect parent involvement, namely, efforts to promote that involvement by the school.

12 Similar sets of regressions were estimated using each of the parental involvement measures listed in table 2 as separate dependent variables. In each case, the results were substantially similar to the results in table 5 . 
Table 5

Models of Parental Participation in School Events, Parental Participation in School Operations, and Principal's Rating of Parental Involvement: Primary Schools

\begin{tabular}{|c|c|c|c|c|c|c|}
\hline & \multicolumn{2}{|c|}{$\begin{array}{l}\text { Participation in } \\
\text { School Events }^{\mathrm{a}}\end{array}$} & \multicolumn{2}{|c|}{$\begin{array}{c}\text { Participation in } \\
\text { School Operations }\end{array}$} & \multicolumn{2}{|c|}{$\begin{array}{l}\text { Principal's Rating of } \\
\text { Parent Involvement }\end{array}$} \\
\hline & Model 1 & Model 2 & Model 1 & Model 2 & Model 1 & Model 2 \\
\hline Charter School & $0.130 * *(2.04)$ & $0.035(0.50)$ & $0.563 * *(5.33)$ & $0.415^{* *}(3.62)$ & $0.417 * *(2.50)$ & $0.263(1.37)$ \\
\hline Charter School $\times$ Urban & $0.279 * *(3.34)$ & $0.278 * *(3.33)$ & $0.035(0.25)$ & $0.130(0.94)$ & $0.442 *(1.94)$ & $0.636 * *(2.64)$ \\
\hline Urban & $-0.174 * *(-3.17)$ & $-0.174 * *(-3.14)$ & $0.011(0.14)$ & $0.008(0.11)$ & $-0.125(-0.87)$ & $-0.110(-0.75)$ \\
\hline Rural & $-0.120 *(-2.09)$ & $-0.113 * *(-2.00)$ & $-0.148 * *(-2.02)$ & $-0.068(-0.92)$ & $-0.059(-0.42)$ & $0.127(0.87)$ \\
\hline$\%$ Minority & $-0.376^{* *}(-3.60)$ & $-0.372 * *(-3.57)$ & $0.026(0.19)$ & $-0.124(-0.87)$ & $-0.533 *(-1.74)$ & $-0.760 * *(-2.40)$ \\
\hline$\%$ Free Lunch & $-0.882 * *(-8.29)$ & $-0.923 * *(-8.99)$ & $-1.094 * *(-8.06)$ & $-1.099 * *(-8.16)$ & $-2.803 * *(-9.03)$ & $-2.736 * *(-8.35)$ \\
\hline \multicolumn{7}{|l|}{ \% Limited English } \\
\hline Proficient & $0.262 *(1.76)$ & $0.223(1.48)$ & $-0.218(-1.17)$ & $-0.209(-1.13)$ & $-2.375(-2.30)$ & $-2.091 *(-1.95)$ \\
\hline \multicolumn{7}{|l|}{$\%$ Limited English } \\
\hline Proficient Squared & & & & & $4.771 * *(3.90)$ & $4.117 * *(3.21)$ \\
\hline Log of Enrollment & & $-0.035(-0.94)$ & & $-0.109 * *(-2.22)$ & & $0.052(0.48)$ \\
\hline External Control & & $-0.029(-1.46)$ & & $0.002(0.08)$ & & $-0.014(-0.27)$ \\
\hline School-Level Control & & $0.087 * *(4.78)$ & & $0.006(0.22)$ & & $0.137^{* *}(2.51)$ \\
\hline Ethnic Homogeneity & & $0.135(1.02)$ & & $-0.185(-1.04)$ & & $-0.035(-0.09)$ \\
\hline Poverty Homogeneity & & $-0.042(-0.33)$ & & $0.993 * *(5.15)$ & & $1.851 * *(4.86)$ \\
\hline \multicolumn{7}{|l|}{ Minority Teachers/Minority } \\
\hline Students & & $-0.016(-0.17)$ & & $0.226(1.32)$ & & $0.426^{*}(1.87)$ \\
\hline \multicolumn{7}{|l|}{ Efforts to Facilitate } \\
\hline Involvement & & $0.034 * *(3.25)$ & & $0.083^{* *}(4.95)$ & & $0.063 * *(2.05)$ \\
\hline
\end{tabular}


Table 5 (continued)

Models of Parental Participation in School Events, Parental Participation in School Operations, and Principal's Rating of Parental Involvement: Primary Schools

\begin{tabular}{|c|c|c|c|c|c|c|}
\hline & \multicolumn{2}{|c|}{$\begin{array}{l}\text { Participation in } \\
\text { School Events }\end{array}$} & \multicolumn{2}{|c|}{$\begin{array}{c}\text { Participation in } \\
\text { School Operations }\end{array}$} & \multicolumn{2}{|c|}{$\begin{array}{l}\text { Principal's Rating of } \\
\text { Parent Involvement }\end{array}$} \\
\hline & Model 1 & Model 2 & Model 1 & Model 2 & Model 1 & Model 2 \\
\hline \multicolumn{7}{|l|}{ Marginal Effect of Charter } \\
\hline School on $\mathrm{P}(\mathrm{Y}=1)^{\mathrm{c}}$ & & & & & -0.050 & -0.054 \\
\hline \multicolumn{7}{|l|}{ Marginal Effect of Charter } \\
\hline School on $\mathrm{P}(\mathrm{Y}=2)^{\mathrm{c}}$ & & & & & -0.142 & -0.146 \\
\hline \multicolumn{7}{|l|}{ Marginal Effect of Charter } \\
\hline School on $\mathrm{P}(\mathrm{Y}=3)^{\mathrm{c}}$ & & & & & 0.044 & 0.054 \\
\hline \multicolumn{7}{|l|}{ Marginal Effect of Charter } \\
\hline School on $\mathrm{P}(\mathrm{Y}=4)^{\mathrm{c}}$ & & & & & 0.148 & 0.146 \\
\hline$N$ & 2,988 & 2,988 & 2,902 & 2,902 & 3,022 & 3,022 \\
\hline$R^{2}$ & 0.378 & 0.393 & 0.130 & 0.169 & & \\
\hline \multicolumn{7}{|c|}{$\begin{array}{l}\text { a Dependent variable defined as in table } 2 \text {. Sample includes respondents to both school and principal survey from charter school states. Estimates are computed using least squares and principal sampling weights } \\
\text { and include controls for state fixed effects, school type (regular, special education, vocational, or other), and grade level (elementary, middle, or unitary). Figures in parentheses are } t \text {-statistics. } \\
\text { bossible responses for dependent variable are } 1=\text { Serious problem, } 2=\text { Moderate problem, } 3=\text { Minor problem, } 4=\text { Not a problem. Models are estimated using maximum likelihood, sample of respondents to } \\
\text { both school and principal survey, and principal weights and include controls for state fixed effects, school type (regular, special education, vocational, or other), and grade level (elementary, middle, or unitary). } \\
\text { Figures in parentheses are } z \text {-statistics. } \\
{ }^{\mathrm{c}} \text { Marginal effects of charter school status in urban areas evaluated at sample averages. } \\
\text { *Statistically significant at .10 level; **Statistically significant at } 05 \text { level. }\end{array}$} \\
\hline
\end{tabular}


greater explanatory power of our models for those schools. ${ }^{13}$ All of the models are estimated with sample weights from the principal survey. The models in columns one through four are estimated using least squares and the models in the final two columns are ordered logits estimated using maximum likelihood. ${ }^{14}$ Each of the models in the table includes controls for state fixed effects, school type (regular, special education, vocational, or other), and grade level (elementary, middle, high, or unitary), in addition to the variables listed.

As in any school-level, cross-sectional analysis, all of our estimates are susceptible to selection bias. Because parents are not randomly assigned to schools, it is difficult to separate the effects of unobserved parent characteristics from the effects of school characteristics. In later sections we present analyses designed to assess indirectly the extent to which estimates of the charter school effect might be influenced by this type of selection. We note, in addition, that selection bias could contaminate the estimated effects of other variables as well, including, for example, school size or school-level autonomy. If the parents who are more inclined to participate in their children's school are particularly attracted to small, autonomous, homogenous schools that promote involvement, then the estimated effects of the institutional measures in our regression would be biased upward and, hence, should be interpreted as upper bound estimates.

Overall, our models explain more of the variation in parental participation in school events (columns 1 and 2) than in school operations (columns 3 and 4) or in the principal's perception of parental involvement (columns 5 and 6). Hence, we begin our discussion by focusing on the models for parental involvement in school events. Those models explain close to 40 percent of the variation in parental participation among schools.

Turning first to model 1 , we find that that the charter school effect $(0.130)$ for schools not in urban areas is large and positive, and that the effect for charter schools in urban areas is even larger as is evident from the positive coefficient on the school-urban interaction term. The sum of the first two entries (0.409) represents the charter school effect for charter schools in urban areas. ${ }^{15}$ With respect to the control variables, the results indicate that parents in urban and in rural areas are less involved in school events than are their counterparts in the base category of suburban schools. Further, the negative coefficients on percentage minority and percentage free lunch indicate, as expected, that primary schools with large proportions of minority and free-lunch-eligible students exhibit less parental involvement. Only the positive coefficient on the percentage LEP students is somewhat surprising.

13 The full results for secondary schools are available from the authors on request. We also estimate models that allowed the charter school effect to differ across states that adopted charter school programs in different years and also across states classified by "strength" of charter school law and by the amount of autonomy the enabling legislation provides to charter schools. Ratings developed by the Center for Education Reform (2001) were used to classify states by "strength" of charter school law and by the amount of autonomy. Age and type of charter school program, specified in a variety of ways, did not consistently show significant influence on the effect of charter schools, nor did they substantially alter the estimates presented here. Nonetheless, we believe the difference in charter school effects across states with different charter school laws is a topic worth further investigation.

14 The samples used in these models are schools from charter school states that responded to both the school and principal surveys and who had nonmissing values for all variables in the model, some of which are from the CCD. Because this sample differs from both the sample of school respondents and the sample of principal respondents, the sampling weights provided by NCES for these surveys are not the exactly correct weights for this analysis. When we asked NCES statisticians about this weighting issue, they suggested that the principal's weight would be a close approximation to the optimal weights. We also estimated each model using weights for the school survey, and the results were very similar.

15 We also estimated models that allowed the effect of charter schools to vary between suburban and rural areas. However, our data are not sufficient to detect any differences between such areas. 
Model 2, in the second column, includes the organizational and institutional variables that we hypothesized might mediate the charter school effect. Among these variables, only two are statistically significant. The first is the positive coefficient on the measure of school-level control, which generates support for the hypothesis that where teachers and principals exert more influence over school programs and policies, parents are more likely to become involved. The second is a measure of the school's efforts to promote involvement. To minimize the statistical problem of multicollinearity, we consolidated the eight types of measures to promote parental involvement, reported in table 4, into a single measure simply by adding them together. Alternative, more complex, methods of consolidation generated similar results. ${ }^{16}$ The positive coefficient on this variable suggests that efforts by schools to promote parental involvement are effective. Questions might be raised, however, about the direction of causality. In equations not shown, we used instrumental variables to try to isolate the causal impact of efforts to promote involvement. These estimates generally support the conclusion that efforts to promote parental involvement are effective. ${ }^{17}$

By comparing the coefficients on the charter school indicators in model 2 to those from model 1, we can determine how much of the difference in parental involvement in school events between charter schools and traditional public schools is attributable to the institutional and organizational factors that we were able to quantify. For nonurban areas, the fact that the coefficient of the charter school indicator in model 2 is only about onequarter that in model 1 indicates that about three-quarters of the estimated difference in parental participation in those areas is attributable to organizational and institutional factors. ${ }^{18}$ The same comparison for charter schools in urban areas is based on the sum of the first two coefficients from each model. In this case, the estimated effect of charter school status on parental participation in school events decreases from 0.409 standard deviations $(0.130+0.279)$ in model 1 to 0.313 standard deviations $(0.035+0.278)$ in model 2 , which suggests that the institutional factors account for about 23 percent of the charter school effect in urban areas. Though not shown, comparable calculations for parental participation in school events in secondary schools indicate that the institutional and organizational factors account for about 30 percent of the charter school effect in urban areas.

Many of the results in the first panel of table 5 are confirmed for the other measures of parental involvement. In particular, positive charter school effects emerge for parental

16 We used methods drawn from item response theory (ITR) to calculate scores that essentially weight each effort indicator according to the proportion of schools that make that particular effort and the ability of that item to distinguish between high-effort and low-effort schools. These ITR scores had a 0.96 correlation with the simple sums, and using the ITR scores in model 2 provided virtually the same results as those reported here. We also estimated models that distinguished efforts to promote parental involvement at school from efforts to promote parental involvement at home. However, factor analysis positing two factors did not strongly confirm two separate factors underlying the eight indicators, and when both measures were included in the regression analysis, they showed similar relationships to the parental involvement measures.

17 In these estimations, the measure of effort to promote parental involvement in other schools in the same district was used as the primary excluded instrument. Overidentification tests confirm the validity of this instrument. The estimated effects of efforts to facilitate involvement at school are somewhat larger when the measure of these efforts is treated as endogenous. Because the new estimates are relatively imprecise, however, the estimated effects of efforts to facilitate involvement are not always statistically significant. These results are available from the authors on request. 18 A significance test using the simultaneous covariance matrix for model 1 and model 2 indicates that the equality of the charter school coefficient in the two models can be rejected at a 0.01 confidence level. Given that the coefficient estimate in model 2 is not significantly different than zero, one could argue that all of the charter school effect in suburban areas is due to the organizational and institutional factors that we are able to quantify. 
involvement in school operations and also as measured by the principal's rating. In contrast to the findings for participation in school events, however, the charter school effect on parental participation in school operations is not significantly larger in urban areas than in nonurban areas. Among the control variables, the percentage of students eligible for free lunch enters with a highly significant, negative effect in all models. Among the institutional variables, efforts to promote parental involvement have significant positive impacts in all models, and school-level control and poverty homogeneity each show significantly positive effects in two of the three models. Thus, we find relatively consistent support for three of our institutional hypotheses. Without data to examine individual parent choices and interactions, we cannot tell whether shared policy preferences, lower levels of conflict, greater levels of social comfort, or some other mechanism accounts for greater levels of participation in economically homogenous schools. However, this finding suggests that segregating parents by economic status stimulates greater parental participation. Whether this positive result can justify other costs of economic segregation is, of course, a different question.

Support for our other hypotheses about the role of particular institutional and organizational characteristics is less consistent. School size, as measured by the log of enrollment, exhibits a significant effect in only one case, a negative effect on participation in school operations. Consistent with our hypothesis, this result suggests that parents are more involved in smaller schools, but comparable effects do not emerge for either of the other measures of parental involvement. Our measure of parent-teacher match - the ratio of minority teachers to minority students - shows the hypothesized positive effect on the principal's rating of parental involvement but does not show significant effects on the other two measures of participation. Neither ethnic homogeneity nor our measure of external control is significant in any of the models.

With respect to parental involvement in school operations, the mediating role of organizational and institutional factors is smaller than in the case of parental participation in school events. The results suggest that those factors account for about 27 percent of the charter school effect in nonurban areas and about 9 percent in urban areas. With respect to the principal's rating of parental involvement, the addition of the organizational and institutional factors does not reduce the charter school effect at all for schools in urban areas. Though not shown, the results for secondary schools are generally comparable in that the inclusion of the organizational and institutional factors has little impact on the estimated charter school effects.

In sum, we find that parental involvement as measured all three ways is substantially higher in charter schools than traditional public schools, even after controlling for school location and the characteristics of the school's students. Furthermore, this "charter school effect" appears to be significantly larger in urban areas than in nonurban areas. We also find that higher levels of school-level control, economic homogeneity, and efforts to promote parental involvement all generate greater parental participation. Weaker and less consistent evidence emerges with respect to the size of the school and the ethnic match between teachers and students.

In most cases, the bulk of the difference in parental involvement between charter and traditional public schools is left unexplained by the organizational and institutional measures we have examined. Admittedly, our ability to measure the match in policy preferences between parents and staff, or in the comfort parents have interacting with other parents and school staff, is weak. Both factors could well elicit greater parental involvement in charter schools than in public schools given that parents actively choose charter schools. In addition, 
we have not measured all of the mechanisms through which competition might influence parental involvement. Nonetheless, these results provide motivation to look elsewhere for an explanation of the relatively high level of parental involvement in charter schools.

\section{DO CHARTER SCHOOLS LOCATE IN AREAS WITH PARTICULARLY ACTIVE PARENTS?}

One such explanation is that charter schools tend to be established in areas where parents have an above-average proclivity to get involved in their children's schools. Though we cannot measure proclivity directly, we can infer it by the past decisions parents have made about engaging in school activities. To test this hypothesis, we examine the levels of parental involvement in traditional public schools that are located in areas from which subsequently established charter schools are likely to draw most of their students. Operationally, we compared the parental involvement in 1993-1994 of schools located within 2.5 miles of where charter schools were later established with schools at greater distances from subsequent charter schools. ${ }^{19}$ If these traditional public schools show higher levels of parental involvement than comparable schools located farther away from charter schools, we can infer that at least part of the high level of parental involvement in charter schools can be explained by their location.

The first column of table 6 presents the results of an ordered logit analysis of the 1993-1994 principal rating of parental involvement, the only one of our three measures that is available in the 1993-1994 SASS. ${ }^{20}$ Once again, we present results only for primary (that is, elementary and middle) schools. The explanatory variables in this model include an indicator of whether the school is within 2.5 miles of a charter school as of 1998-1999, that variable interacted with an urban indicator variable, and the control variables used in table 5. The insignificance of the second coefficient indicates that the effect of being located in the vicinity of a charter school in urban areas does not differ from the effect in nonurban areas. However, an $F$-test reveals that the sum of the two coefficients is significantly positive at the 10 percent level. Thus, we have weak support for the conclusion that in urban areas the traditional public schools that are located in the vicinity of a subsequent charter school exhibit higher levels of parental involvement than other schools. ${ }^{21}$ The estimates imply that urban schools located near where charter schools would come to be located are 10.1 percent less likely to have lack of parental involvement rated as a serious or moderate problem than urban schools located elsewhere (the sum of the -0.030 and -0.071 estimates of marginal effects provided at the bottom of the column), approximately 50 percent of the marginal effect of charter school status on the same probability in table 5, fifth column.

19 In states where charter school enrollments are limited to students from the district where the charter school is located, a school also had to be from a district in which charter schools are located to be counted as a school from which charter schools draw most of their students. To determine whether charter school enrollment was limited to students from the same district in a particular state, we used information from an analysis of charter school legislation conducted by Jennings et al. (1998). In states where the CCD does not identify the district where charter schools are located, but which nonetheless were determined to have this restriction on enrollment, we required that a school be within 2.5 miles of and from the same city as a charter school.

20 The other measures of parental involvement used in table 5 are not available for 1993-1994. Thus, we cannot investigate the distribution of these measures of involvement prior to the introduction of charter schools.

21 We also estimated the models reported in table 6 with being located near a charter school defined as being within 2.5 miles for an urban school, within 5 miles for a suburban school, and within 20 miles for a rural school and obtained very similar results. 
Table 6

Principals' Rating of Parental Involvement, Ordered Logit Analysis: 1993-1994 Primary Schools

\begin{tabular}{lcc}
\hline & Model 1 & Model 2 \\
\hline Within 2.5 Miles of a Charter School in 1998-1999 & $0.002 \dagger(0.01)$ & $0.079 \dagger(0.28)$ \\
Within 2.5 Miles of a Charter School $\times$ Urban & $0.459 \dagger(1.35)$ & $0.328 \dagger(0.91)$ \\
Urban & $0.002(0.01)$ & $0.068(0.43)$ \\
Rural & $-0.058(-0.71)$ & $-0.140(-0.96)$ \\
\% Minority & $-1.070^{* *}(-3.58)$ & $-1.089^{* *}(-3.70)$ \\
\% Free Lunch & $-1.910^{* *}(-6.66)$ & $-1.864^{* *}(-6.34)$ \\
\% Limited English Proficient & $-3.438^{* *}(-2.71)$ & $-2.663^{* *}(-2.14)$ \\
\% Limited English Proficient Squared & $4.052^{* *}(2.56)$ & $2.853^{*}(1.78)$ \\
Log of Enrollment & & $-0.418^{* *}(-4.04)$ \\
External Control & & $0.041(0.75)$ \\
School-Level Control & & $0.164^{* *}(2.93)$ \\
Poverty Homogeneity & & $0.986^{* *}(2.61)$ \\
Ethnic Homogeneity & & $0.582(1.51)$ \\
Minority Teachers/Minority Students & & $-0.070(-0.19)$ \\
Marginal Effect of Charter School Location on P(Y $=1)^{\mathrm{b}}$ & -0.030 & -0.027 \\
Marginal Effect of Charter School Location on P(Y $=2)^{\mathrm{b}}$ & -0.071 & -0.063 \\
Marginal Effect of Charter School Location on P(Y $=3)^{\mathrm{b}}$ & 0.008 & 0.013 \\
Marginal Effect of Charter School Location on P(Y $=4)^{\mathrm{b}}$ & 0.093 & 0.077 \\
$N$ - & 2,464 & 2,464 \\
\hline
\end{tabular}

Note: Dependent variable is principal's response to question "to what extent is lack of parental involvement a problem" in the 19931994 SASS. Possible responses for dependent variable are $1=$ Serious problem, $2=$ Moderate problem, $3=$ Minor problem, $4=$ Not a problem. Models are estimated using primary schools from charter school states with both school and principal responses. All models are estimated using principal weights and controls for state fixed effects, school type (regular, special education, vocational, or other), and grade level (elementary, middle, or unitary). Figures in parentheses are $t$-statistics.

${ }^{\mathrm{a}}$ This $=1$ if school is within 2.5 miles of where a charter school would come to be located and, for states that restrict charter school students to schools in a particular district, in a district or city in which charter schools would come to be located.

${ }^{b}$ Marginal effects of being located near a charter school for urban schools evaluated at sample averages.

*Statistically significant at .10 level; **Statistically significant at 0.05 level.

†Indicates that the combined coefficient (i.e., the estimated effect of being within 2.5 miles of a charter school in an urban area) is statistically significant at the .10 level.

Model 2 in table 6 adds the organizational and institutional variables. ${ }^{22}$ The school size, school-level control, and poverty homogeneity variables each have significant effects in the expected direction. The effects of external control, ethnic homogeneity, and parentteacher ethnic match are insignificant. As in model 1, the marginal effect of being located within 2.5 miles of a subsequent charter school is statistically significant for schools in urban areas at the .10 level.

\section{DO CHARTER SCHOOLS REDUCE PARENT INVOLVEMENT IN NEARBY PUBLIC SCHOOLS?}

Finally, we examine the effect of charter schools on the involvement of parents in nearby traditional public schools. This issue is important not only in its own right, but also because it sheds light on another potential explanation for the relatively high level of parental 
Table 7

Change in Principal's Rating of Parental Involvement between 1993-1994 and 1999-2000

\begin{tabular}{|c|c|c|}
\hline & $\begin{array}{c}\text { Probability of } \\
\text { Principal's Response } \\
\text { Dropping at } \\
\text { Least One Rating }^{\text {a }}\end{array}$ & $\begin{array}{c}\text { Probability of } \\
\text { Principal's Response } \\
\text { Dropping at } \\
\text { Least Two Ratings }^{\text {b }}\end{array}$ \\
\hline Within 2.5 Miles of a Charter School in $1998-1999^{c}$ & $0.300(0.87)$ & $0.738 *(1.88)$ \\
\hline Change in $\%$ Minority & $0.430(0.52)$ & $-0.205(-0.17)$ \\
\hline Change in $\%$ Free Lunch & $0.684 *(1.64)$ & $1.025(1.46)$ \\
\hline Change in \% Limited English Proficient & $1.033(1.43)$ & $3.770 *(1.66)$ \\
\hline Marginal Effect of Charter School Competition ${ }^{\mathrm{d}}$ & 0.074 & 0.148 \\
\hline$N$ & 622 & 363 \\
\hline \multicolumn{3}{|c|}{$\begin{array}{l}\text { Note: Logit models are estimated using sample of schools with responses to school and principal surveys in both } 1993-1994 \text { and } 1999 \\
2000 \text { SASS. Models control for school type (regular, special education, vocational, or other) and grade level (elementary, middle, high, } \\
\text { or unitary), and treat state effects as random. Figures in parentheses are } z \text {-statistics. } \\
{ }^{\text {a }} \text { Possible responses to lack of parental involvement question are } 1 \text { = Serious problem, } 2 \text { = Moderate problem, } 3=\text { Minor problem, } \\
4=\text { Not a problem. Estimates are calculated using only observations where principal's rating in 1993-1994 is } 2 \text { or higher. } \\
{ }^{b} \text { Estimates calculated using only observations where principal's rating in } 1993-1994 \text { is } 3 \text { or higher. } \\
{ }^{c} \text { This }=1 \text { if school is within } 2.5 \text { miles of where a charter school would come to be located and, for states that restrict charter school } \\
\text { students to schools in a particular district, in a district or city where charter schools would come to be located. } \\
{ }^{\mathrm{d} E v a l u a t e d ~ a t ~ s a m p l e ~ a v e r a g e s . ~} \\
{ }^{*} \text { Statistically significant at } .10 \text { level; } * * \text { Statistically significant at } .05 \text { level. }\end{array}$} \\
\hline
\end{tabular}

involvement in charter schools, namely, the possibility that charter schools draw the more involved parents away from the nearby schools.

For this analysis we use the sample of schools included in both the 1993-1994 and 1999-2000 SASS to examine the change in the principal's rating of parental involvement. The first column of table 7 analyzes the effect of being within 2.5 miles of a charter school on the probability that the principal's rating drops by at least one category. ${ }^{23}$ Only schools from states with charter schools and that were rated as having no problem, a minor problem, or a moderate problem with parental involvement in 1999-2000 are used in this analysis. The second column in table 7 analyzes the effect of being within 2.5 miles of a charter school on the probability that the principal's rating of the extent to which parental involvement is a problem drops by two or more categories. ${ }^{24}$ Both models include controls for changes in student demographics, school type, and grade level, and both treat state effects as random. ${ }^{25}$

The estimates in table 7 suggest that schools located near charter schools are more likely than other schools to see lack of parental involvement become a more serious problem between 1993-1994 and 1999-2000. Those estimates suggest that in schools located within 2.5 miles of a charter school, principals are 7.4 percent more likely to see lack of parental involvement become a more serious problem and 14.8 percent more

23 Thus, the principal's rating must drop from no problem to a minor, moderate, or serious problem, from a minor problem to a moderate or serious problem, or from a moderate problem to a serious problem. In states where charter school enrollments are limited to students from the district where the charter school is located, a school also had to be from a district in which charter schools were located to be classified as being near a charter school. 24 Thus, the principal's rating must drop from no problem to a moderate or serious problem or from a minor problem to a serious problem.

25 We also estimated models that treat the state effects as fixed. The estimates from the random effects model are more precise, and Hausman specification tests do not reject the null hypotheses that the observed covariates are uncorrelated with the state effects, which supports the validity of the random effects model. 
likely to see the problem change from nonexistent to moderate or serious or from minor to serious. These results are merely suggestive since we are not able to address many potential alternative explanations for the decline in the principal's rating of parental involvement in schools located near charter schools. Prior trends, changes in the expectations of principals in schools facing charter school competition, and other changes in school policies cannot be ruled out. Also, the small samples available for this analysis are not necessarily nationally representative. Nonetheless, our results, specifically the statistically significant estimate in the last column of table 7, provide some weak evidence that not only are charter schools more likely to be located in areas where parents are actively involved in their children's schools, but also charter schools attract the more active parents from the parent pool.

\section{CONCLUSIONS}

Our evidence from the 2000 Schools and Staffing Survey (SASS) confirms that parents are more involved in charter schools than in observationally similar traditional public schools. Furthermore, we find evidence that the organizational and institutional characteristics of charter schools account for part of the difference. In particular, higher levels of schoollevel autonomy, poverty homogeneity, and greater efforts to promote parent involvement in charter schools consistently show a statistically significant, positive relationship to our parental involvement measures. We find weaker support for the hypotheses that the smaller size of charter schools and higher ratios of minority teachers to minority students encourage more parental involvement. The fact that the inclusion of the various institutional and organizational measures reduces the estimated size of the charter school effect provides some evidence that the institutional characteristics of charter schools help to elicit greater parental involvement.

We also find that part of the differentially high parental involvement in urban elementary and secondary charter schools is attributable to the fact that these schools tend to be established in areas with particularly active and involved parents. Further, we find weak evidence suggesting that parental involvement in nearby public schools tended to decline after the establishment of charter schools. Thus, even from the group of relatively involved parents, the charter schools may be attracting the more active parents. Thus, our results indicate that high levels of parental involvement in charter schools are most likely attributable to student sorting, as well as to the organizational and institutional differences between charter schools and traditional public schools. In so far as such sorting reduces parental involvement in traditional public schools and segregates students with different levels of family support, these findings suggest that the impacts of charter schools through the mechanism of parental involvement are more mixed than would be inferred from the observation of high parental involvement in charter schools alone.

\section{REFERENCES}

Antone, Nan M., and Sara S. McLanahan. 1991. Family structure, parental practices, and high school completion. American Sociological Review 56 (3): 309-20.

Barker, Roger G. 1964. Big school, small school: High school size and student behavior. Stanford, CA: Stanford University Press.

Bifulco, Robert, and Helen F. Ladd. Forthcoming. The impacts of charter schools on student achievement: Evidence from North Carolina. Education Finance and Policy 1 (1). 
Brandl, John E. 1998. Civic values in public and private schools. In Learning from school choice, ed. P. E. Peterson and B. C. Hassel, 55-82. Washington, DC: Brookings Institution.

Chubb, John E., and Terry M. Moe. 1990. Politics, markets, and America's schools. Washington, DC: Brookings Institution.

Center for Education Reform. 2001. Charter school laws: Scorecard and rating (May 2001). http://www.edreform.com/ranking.htm (accessed September 28, 2001).

Hill, Paul, Lawrence C. Pierce, and James W. Guthrie. 1997. Reinventing public education: How contracting can transform America's schools. Chicago: University of Chicago Press.

Hirschman, Albert O. 1970. Exit, voice, and loyalty: Responses to declines in firms, organizations, and states. Cambridge, MA: Harvard University Press.

Holmes, George M., Jeff DeSimone, and Nicholas G. Rupp. 2003. Does school choice increase school quality? National Bureau of Economic Research Working Paper No. 9683.

Hoxby, Caroline M. 1999. The effects of school choice on curriculum and atmosphere. In Earning and learning: How schools matter, ed. S. Mayer and P. E. Peterson. Washington, DC: Brookings Institution.

2003. School choice and school productivity: Could school choice be a tide that lifts all boats? In The economics of school choice, ed. C. M. Hoxby, 287-341. Chicago: University of Chicago Press.

Jennings, Wayne, Eric Premack, Andrew Adelmann, and Debra Solomon. 1999. A comparison of charter school legislation: Thirty-three states and the District of Columbia incorporating legislative changes through October, 1998. Submitted to U.S. Department of Education by RPP International.

Kerbow, David, and Annette Bernhardt. 1993. Parent intervention in the school in the context of minority involvement. In Parents, their children, and schools, ed. B. Schneider and J. S. Coleman, 43-67. Boulder, CO: Westview Press.

Kiser, Larry L. 1984. Toward an institutional theory of citizen co-production. Urban Affairs Quarterly 19 (4): 485-510.

McGinnis, Michael D. 1999. Introduction. In Polycentricity and local public economies, ed. M. D. McGinnis, 1-27. Ann Arbor: University of Michigan Press.

McMillan, Robert. 1999. Competition, parental involvement, and public school performance. Ph.D. diss., Stanford University.

Moody, James. 2001. Race, school integration, and friendship segregation in America. American Journal of Sociology 107 (3): 679-716.

Muller, Chandra. 1993. Parent involvement and academic achievement: An analysis of family resources available to the child. In Parents, their children, and schools, ed. B. Schneider and J. S. Coleman, 13-42. Boulder, CO: Westview Press.

Murnane, Richard J., and Frank Levy. 1998. Standards, information, and the demand for student achievement. Federal Reserve Bank of New York Economic Policy Review 4 (1): 117-24.

Ostrom, Vincent, Robert L. Bish, and Elinor Ostrom. 1988. Local government in the United States. San Francisco: Institute for Contemporary Studies.

Ostrom, Vincent, and Elinor Ostrom. 1977. Public goods and public choices. In Alternatives for delivering public services: Toward improved performance, ed. E. S. Savas, 7-49. Boulder, CO: Westview Press.

Parks, Roger B., Paula C. Baker, Larry L. Kiser, Ronald J. Oakerson, Elinor Ostrom, Vincent Ostrom, Stephen L. Percy, Martha Vandivort, Gordon P. Whitaker, and Rick K. Wilson. 1981. Consumers as coproducers of public services: Some economic and institutional considerations. Policy Studies Journal 9 (7): 1001-11.

Percy, Stephen L. 1984. Citizen participation in the coproduction of urban services. Urban Affairs Quarterly 19 (4): 431-46.

Purkey, Stewart C., and Marshall S. Smith. 1983. Effective schools: A review. Elementary School Journal 85 (4): 427-52.

Schneider, Mark, Paul Teske, and Melissa Marschall. 2000. Choosing schools: Consumer choice and the quality of American schools. Princeton, NJ: Princeton University Press.

Schneider, Mark, Paul Teske, Melissa Marschall, Michael Mintrom, and Christine Roch. 1997. Institutional arrangements and the creation of social capital: The effects of public school choice. American Political Science Review 91 (1): 82-93. 
Sui-Chu, Esther H., and J. Douglas Willms. 1996. Effects of parental involvement on eighth-grade achievement. Sociology of Education 69 (2): 126-41.

Tourkin, Steven C., Kathleen W. Pugh, Sharon E. Fondelier, Randall J. Parmer, Cornette Cole, Betty Jackson, Toni Warner, et al. 2004. 1999-2000 Schools and Staffing Survey (SASS) data file user's manual. NCES 2004-303. Washington, DC: National Center for Education Statistics, U.S. Department of Education.

Witte, John F., and Daniel J. Walsh. 1990. A systematic test of the effective schools model. Educational Evaluation and Policy Analysis 12 (2): 188-212. 